\title{
Climatological and social fallacies about COVID-19 pandemic
}

\author{
Ambar Farooq ${ }^{1} \cdot$ Uttam Kumar $^{2}$ - Junaite Bin Gais Uddin ${ }^{3} \cdot$ Muhammad Haroon U. Rashid $^{4} \cdot$ Matoor Mohsin Gilani $^{4}$. \\ Taimoor Hassan Farooq ${ }^{5}$. $\cdot$ Awais Shakoor ${ }^{6} \cdot$ Matloob Ahmad $^{1}$
}

Received: 9 July 2020 / Revised: 13 April 2021 / Accepted: 19 April 2021 / Published online: 20 May 2021

(c) Society for Environmental Sustainability 2021

\begin{abstract}
Coronavirus disease (COVID-19) has emerged as a major global challenge since 2019. With the fast rise in the infected cases and deaths worldwide, many environmental and climate-related myths and fallacies spreaded fast. These fallacies include virus cannot spread in hot and humid conditions, cold weather can inhibit the virus, drinking hot water and sunlight can help cure the COVID-19, ultraviolet (UV) disinfectant lamps and UV rays from sunlight can kill the virus, use of hairdryers and hot showers for virus prevention, etc. Social norms and mindset of the people in the world towards a pandemic are quite similar. The primary purpose of this article is to enlighten the readers regarding these climatological misconceptions and social fallacies, helping spread proper knowledge and manage the outbreak of this deadly pandemic.
\end{abstract}

Keywords Community safety $\cdot$ Public health $\cdot$ Environmental-related myths $\cdot$ Misconceptions $\cdot$ Coronavirus (COVID-19)

\section{Introduction}

A novel coronavirus $(\mathrm{nCoV})$ originated in China in late December 2019, and Wuhan was the epicenter of this pandemic (Ahmadi et al. 2020; Doğan et al. 2020; Shakoor et al. 2020). Massive number of people were infected by this virus, as situation got worse with each passing day (Guan et al. 2020). The disease was officially called coronavirus disease

Ambar Farooq and Uttam Kumar have contributed equally to this work.

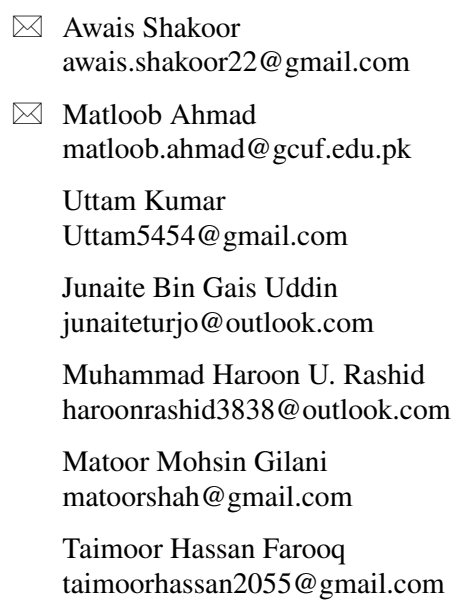

1 Department of Chemistry, Government College University Faisalabad, Faisalabad 38000, Punjab, Pakistan
(COVID-19) by World Health Organization (WHO) (Ma et al. 2020), caused by severe acute respiratory syndrome coronavirus 2 (SARS-CoV-2). It was the third coronavirus infection after severe acute respiratory syndrome (SARS) and Middle East respiratory syndrome (MERS) (Zhu and Xie 2020). After being exposed to the virus, it can take up to 14 days for symptoms of COVID-19 to appear. The main symptoms to look out for are coughing, shortness of breath, fever, and sore throat. Moreover, COVID-19 has also been identified in feces of symptomatic and asymptomatic

2 College of Plant Protection, Fujian Agriculture and Forestry University, Fuzhou 350002, Fujian, People's Republic of China

3 Center for Molecular Cell and Systems Biology, College of Life Science, Fujian Agriculture and Forestry University, Fujian 350002 Fuzhou, People's Republic of China

4 College of Forestry, Fujian Agriculture and Forestry University, Fuzhou 350002, Fujian, People's Republic of China

5 College of Life Science and Technology, Central South University of Forestry and Technology, Changsha 410004, Hunan, People's Republic of China

6 Department of Environment and Soil Sciences, University of Lleida, Avinguda Alcalde Rovira Roure 191, 25198 Lleida, Spain 
patients (Dong et al. 2020; Holshue et al. 2020; Liu et al. 2020; Wölfel et al. 2020). Initially, different case studies reported that COVID-19 had a low fatality rate (2.3\%) (Shi et al. 2020; She et al. 2019) as compared to MERS (34.4\%) and SARS (9.2\%) (Wu and McGoogan 2020; Ceccarelli et al. 2020). However, a research study found that the number of COVID-19 patients doubled every 6.4 days identifying that COVID-19 was a much more dangerous and infectious disease than MERS and SARS (Wu and McGoogan 2020).

With the past experiences of previous pandemics, it is known fact that perturbations and misapprehensions arise in the people's minds when a diseasespreads so quickly in the population (Leslie et al. 2013). In today's world, when almost people are connected to a vast internet network, the main concern is the fast flow of information (Leiner et al. 2009; Goodchild and Glennon 2010). When this information becomes misinformation, it becomes a significant issue for the governments and health officials (Bode and Vraga 2018). This misinformation may also take the public into an unnecessary chaotic situation and may even threaten many lives. Misinformation can leed society to inappropriate behavior and to many social fallacies (Qureshi and Shaikh 2006). Removal of these misinformations from spreading in the population along with the virus and providing the correct information will help correct society's perception towards a pandemic and will help lower the disease risk and spread (Reyna 2012). Social norms are similar worldwide due to the same mindset of the population at large (Hassan and Azfar 2003; Khilji 2012). During a pandemic, it becomes essential to know about the attitude, knowledge, social norms, and behavior of a society (Ferrante et al. 2011). This commentary covers the recent climate-related myths and social fallacies that were spread during the COVID-19 pandemic. It gives a reasonable and scientific explanation of such social misconceptions by using references from various resources.

\section{Climate-related myths}

While many believe that the novel coronavirus cannot spread in hot and humid conditions, the data shows a different story (Zhu and Xie 2020). Although some researchers reported a decline in cases during high-temperature conditions (Bashir et al. 2020a, b; Dogan et al. 2020; Ma et al. 2020; Rehman et al. 2020; Wang et al. 2020), others said the opposite (Jamil et al. 2020; Zhu and Xie 2020); moreover, nothing is officially declared by World Health Organization (WHO) about this. According to the recently published pole report on infection and death, this virus can leave a devastating impact in any climate, including the hottest and humid areas (Jamil et al. 2020). For example, the United Arab Emirates and Saudi Arabia are among the hottest countries with $37.75^{\circ} \mathrm{C}$, and $36.5^{\circ} \mathrm{C}$ average annual temperature. Both these countries are suffering from the impact of COVID-19 virus outbreak (Livingston et al. 2020). Humidity has also proven to be a mare myth in the case of the COVID-19 outbreak. Some of the most humid places like Arizona, California, Bangkok, Kuala Lumpur, Malaysia, Indonesia, Panama, and Singapore etc., with numerous COVID-19 infections and deaths, have proved this hypothesis nothing but wrong (Ahmadi et al. 2020; Ministry of Health of the Republic of Panama 2020; World Health Organization 2020). Moreover, available data shows that some of these regions are not new to viral outbreaks. MERS affected many in the hot conditions of the Gulf region back in 2012 (Aburizaiza et al. 2014; Almutairi et al. 2015). It indicates that coronavirus can survive, infect, and create destruction in any climate (Jamil et al. 2020; Zhu and Xie 2020).

There has been a myth that drinking hot water and sunlight can help cure the coronavirus, but to date, there is no proof that these two things can control and kill COVID-19 virus (World Health Organization 2020). Drinking lukewarm water and getting sufficient sunlight can have some other health benefits, but it doesn't directly relate to preventing or killing the virus. Another myth was cold weather and snow can kill or inhibit the new coronavirus. WHO has already declined this theory (Ali et al. 2020). There is no scientific evidence that cold weather or snow can kill the virus or prevent infection. In China, it spread in the winter season, including the northern regions with very low temperatures and regular snowfall.

Another myth was that ultraviolet (UV) disinfectant lamps and taking UV rays from sunlight kills the virus (World Health Organization 2020). Among UV-A, UV-B, and UV-C, UV-C can demolish any genetic material, including infections. In that sense, it can be assumed that exposing the body to sun may kill the virus particles present on the skin surface (Hopman et al. 2020). Even if counting this assumption, it can't treat people who are already affected because the sunlight can't pass through the outer layer of skin and reach the internal organs. UV-C rays from sun are unable to reach to surface environment as it is absorbed by the atmosphere and the available data on SARS, a closely related virus to novel coronavirus, shows that exposing the virus to the UV-A rays for $15 \mathrm{~min}$ has no impact on the infection rate of SARS virus (Kariwa et al. 2006). UV-C rays commonly used as disinfectanting rays were inadequate to inactivate the SARS virus. Moreover, according to the WHO, UV-C is highly prohibited for operating on the skin beacuse it has a high chance of causing severe damage to human health.

Many around the world believe that thermal scanners can detect the virus. A simple understanding of the mechanism of the thermal scanner is enough to remove this misconception. Thermal scanners only detect people with higher body 
temperature, not the virus. According to the recent article, in most COVID-19 infections, it can take up to 14 days for symptoms to appear and hence thermal scanners may not be effective during this time period (Li et al. 2020) (Fig. 1).

\section{Social fallacies about COVID-19 pandemic}

As alcohol is used in almost all kinds of sanitizers (Sakamoto et al. 2010), so it became a common social fallacy among people that drinking alcoholic beverages can control the spread of COVID-19. Alcohol is a commonly used disinfecting liquid that needs to be handled carefully while operating on the human body as it is harmful to mucous membranes (i.e. eyes, mouth). Excessive alcohol thronging or consumption can increase the risk to human health. Ethanol kills microorganisms by dissolving the lipid membrane and denaturing the protein. However, ethanol needs to reach the microorganism to kill it.

Garlic is believed to have antibiotic properties in most Indian Ayurveda books (Yoshida et al. 1987); it made people think that eating garlic helps prevent the new coronavirus infection. Its scientifically proven that garlic is a healthy food with antimicrobial properties; however, there is no evidence available that garlic has protected people from the coronavirus (World Health Organization 2020).

Some people believe that the coronavirus can spread through 5G mobile networks. While discussing this in scientific terms, radio waves/mobile networks can never be the medium of travel for viruses. There is enough research available that proves COVID-19 is spreading through droplets when an infected person coughs, sneezes, or speaks. People can also be infected by touching a contaminated surface and then touching their eyes, mouth, or nose (Mittal et al. 2020).

It was a point of discussion between people that vaccines against pneumonia protect against the coronavirus. Still, there has been no proven research that supports such results. Nabity-Grover et al. (2020) reported that vaccines against pneumonia, such as pneumococcal vaccine and Hemophilic influenza type B (Hib) vaccine, do not protect against the coronavirus. According to the researcher from Trinity College Dublin, BCG (Bacillus Calmette-Guerin) vaccine can be one reason for the fewer cases of COVID19 in South- and Southeast Asia compared to Europe and USA. BCG vaccine can train the immune system for responding to a variety of infections such as viruses, bacteria, and parasites (Larsen et al. 2020). Still, there is no proven research that can show the effect of this vaccine on COVID-19 prevention.

It was rational thinking that gargling regularly with saline water can help prevent the infection of COVID-19. Still, there is no evidence that gargling can save people from the new coronavirus disease. There may be some soothing effect of saline water gargling on a sore throat; however, this kind of practice cannot stop COVID-19 virus infection (World Health Organization 2020). Few reports claimed that regular rinsing of the nose with saline might help people recovering faster from the common cold, but no such evidence is available in COVID-19.
Fig. 1 Environmental/climatic myths and misconceptions related to COVID-19

\section{Sun exposure can help to prevent infection}
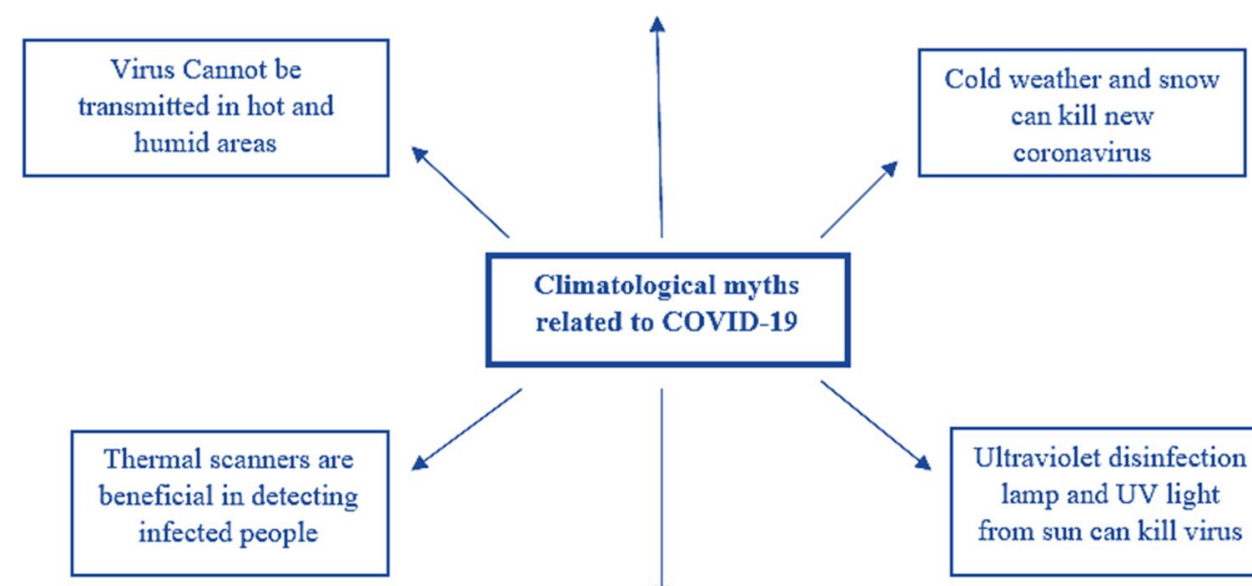

Climatological myths related to COVID-19

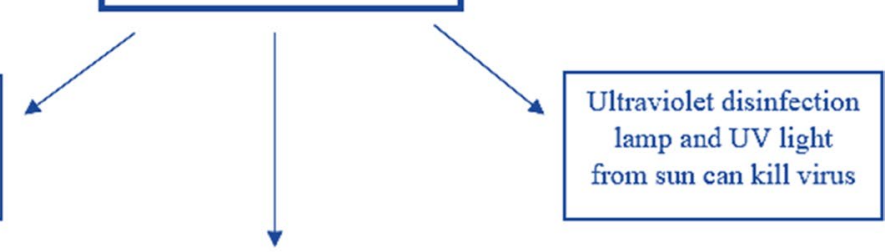

Spraying alcohol around

in the air and on the body

can prevent from virus 
There is another fallacy that hot water can prevent from COVID-19 infection. Average body temperature will remain nearly constant from 36.5 to $37^{\circ} \mathrm{C}$ (Grodzinsky and Levander 2020), regardless of the temperature of water one uses. Sometimes, the hot water bath can have a burning effect on the human body (Bando et al. 2020). During infection, the human body tries to kill the virus by raising body temperature. A hot bath cannot induce fever or kill the virus. Hand dryers also cannot be considered as a preventive measure for COVID-19 infection.

It's tough to imagine food without any spices and condiments in many regions of the world (Kalra et al. 2020). These spices have many health benefits for the body (Wacker 2020). Due to these health benefits, much research has been done on individual herbs to know more about the claims made by many people for these spices (Sanlier and Gencer 2020). In recent days there are many claims such as ginger, turmeric, etc., can help prevent from infection of new coronavirus. South Asian people have used spices for a long time, and many spices have shown antimicrobial properties (Hashmi 2020). Still, there is no scientific evidence that these spices can prevent COVID-19 infection. Usually, people have a question in their minds that infection of new coronavirus means it may have a lifelong impact. However, most of the people who get COVID-19 disease recover and eliminate the virus from their bodies (Fig. 2).

\section{Myths related to Covid-19 vaccine}

Pfizer, Moderna, AstraZeneca, Sputnik V and Sinopharm vaccines got approval in many countries such as the USA, UK, European Union, India, Russia, China etc. However, many around the world believe that due to their quick development, the vaccines are not safe. Previous studies related to the coronaviruses, such as MERS and SARS, helped in speed up of the process for development of vaccine against SARS-CoV-2. The vaccine was developed rapidly due to scientific advancements, but the vaccine's clinical trials and effectiveness were not compromised (Vashishtha and Kumar 2020). Many believe that vaccines can have long-term effects on health. More or less, the side
Fig. 2 Social fallacies among people related to COVID-19

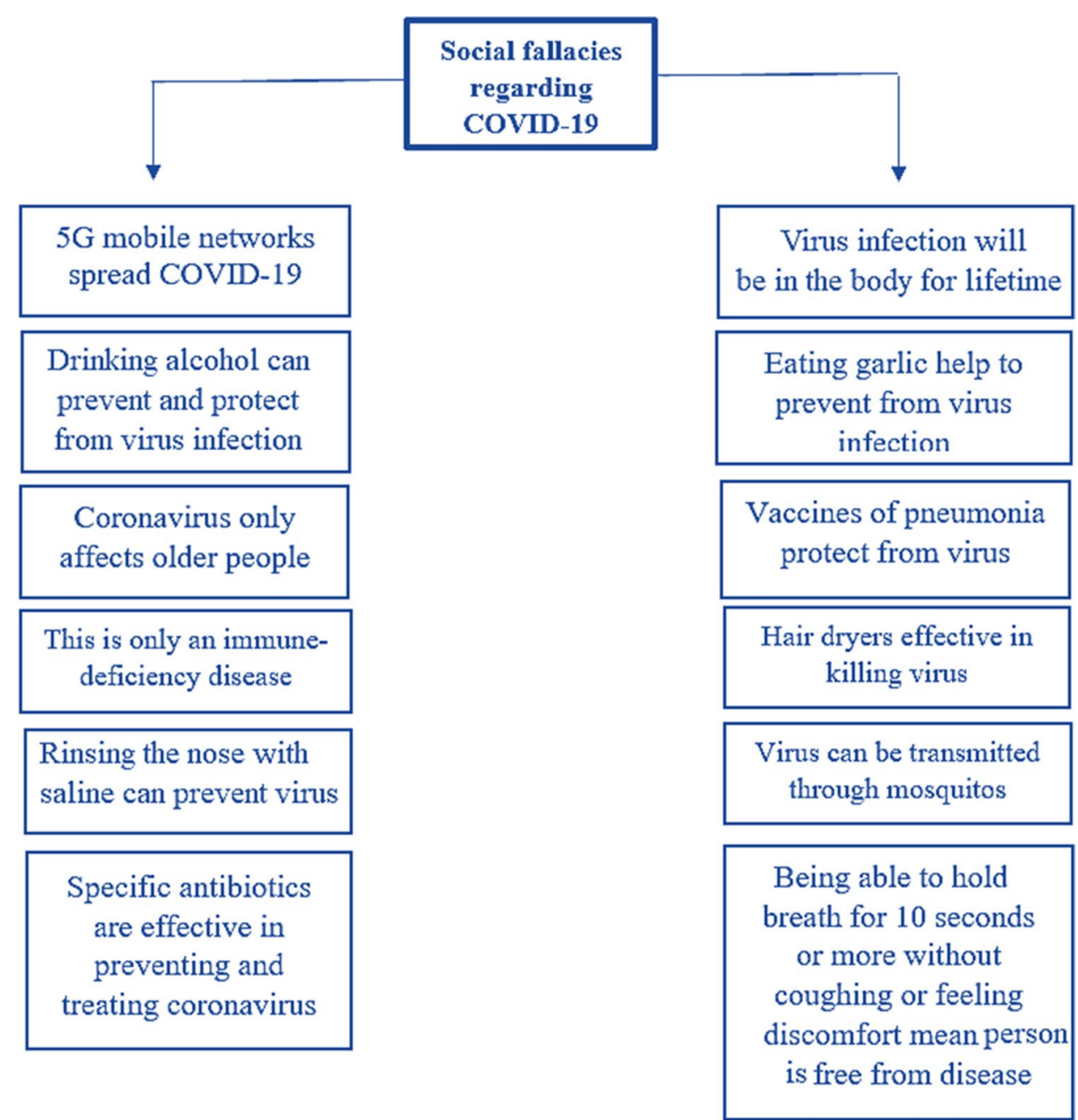


effects, reactions, and complications of the vaccines can occur within minutes to hours or sometimes a few days of receiving the vaccine in a fraction of the cases (Baden et al. 2020a, b). However, in most of the cases there are no side effects and immunity against the virus is high. Preliminary evidences have showed that a vaccine will give better protection and result in lower moratlity against the novel coronavirus (Lee et al. 2020).

Many vaccine developers are using messenger RNA (m RNA) to protect from SARS-CoV-2 (Zhang et al. 2020). Scientifically it is proven that $\mathrm{m}$ RNA only provides the blueprint to manufacture the proteins, which will prevent COVID-19 infection (Cohen 2020). Many around the globe also believe that the vaccine will make people infertile. There are no clinical trials that provide single evidence regarding the effect of the Covid-19 vaccine on the human reproductive system and sexual behavior (Babaei et al. 2020). In contrast, a COVID-19 positive pregnant female can have a miscarriage or premature labor (Boelig et al. 2020).

\section{Concluding remarks}

People mindset towards a threat and unforeseen issue, especially related to pandemics, is quite similar around the globe. Majority of the population starts believing in climatic/ environmental-related myths and social fallacies regarding prevention measures and cure. Knowing about these myths and misconceptions can help the government and the health officials to make a road map for countering the pandemic by creating awareness among the community through different ways such as social and print media. By and large, the truth is not merely a fierce battle with ignorance and fallacy, but, first and foremost, with preconceived ideas and aprioristic conceptions. In these challenging times of fight against a deadly novel virus making the mindset of people free of climatological myths and social fallacies is important. People can be aware of a correct and better way to save themselves from this deadly virus. To win the battle against any pandemic, it's essential to establish a sustainable and effective disease management system which should include countering the myths and fallacies surrounding it.

Acknowledgements This research did not receive any specific funding from any government or private organization.

Data availability The information used during the current study is taken from available websites and the below-mentioned references.

\section{Declarations}

Conflict of interest The authors declare that they have no conflict of interest.

\section{References}

Aburizaiza AS, Mattes FM, Azhar EI, Hassan AM, Memish ZA, Muth D, Meyer B, Lattwein E, Müller MA, Drosten C (2014) Investigation of anti-Middle East respiratory syndrome antibodies in blood donors and slaughterhouse workers in Jeddah and Makkah, Saudi Arabia, fall 2012. J Infect Dis 209(2):243-246

Ahmadi M, Sharifi A, Dorosti S, Ghoushchi SJ, Ghanbari N (2020) Investigation of effective climatology parameters on COVID-19 outbreak in Iran. Sci Total Environ 17:138705

Ali SM, Hashmi A, Hussain T (2020) Causes and treatment of Covid19: myths vs facts. Pak J Pharm Sci 33(4):1731-1734

Almutairi KM, Al Helih EM, Moussa M, Boshaiqah AE, Saleh Alajilan A, Vinluan JM, Almutairi A (2015) Awareness, attitudes, and practices related to coronavirus pandemic among public in Saudi Arabia. Fam Community Health 38(4):332-340

Babaei F, Mirzababaei M, Nassiri-Asl M, Hosseinzadeh H (2020) Review of registered clinical trials for the treatment of COVID19. Drug Dev Res. https://doi.org/10.1002/ddr.21762

Baden LR, El Sahly HM, Essink B, Kotloff K, Frey S, Novak R, Diemert D, Spector SA, Rouphael N, Creech CB, McGettigan J (2020a) Efficacy and safety of the mRNA-1273 SARS-CoV-2 vaccine. N Engl J Med 30

Baden LR, El Sahly HM, Essink B, Kotloff K, Frey S, Novak R, Diemert D, Spector SA, Rouphael N, Creech CB, McGettigan J (2020b) Efficacy and safety of the mRNA-1273 SARS-CoV-2 vaccine. N Engl J Med. https://doi.org/10.1056/NEJMoa2035389

Bando H, Nakanishi A, Yoshioka A, Nishikiori Y (2020) Thermal therapy for patients with heart disease from the perspective of integrative healthcare. Curr Res Comp Alt Med

Bashir MF, Ma B, Komal B, Bashir MA, Tan D, Bashir M (2020a) Correlation between climate indicators and COVID-19 pandemic in New York, USA. Sci Total Environ 20:138835

Bashir MF, Jiang B, Komal B, Bashir MA, Farooq TH, Iqbal N, Bashir M (2020b) Correlation between environmental pollution indicators and COVID-19 pandemic: a brief study in Californian context. Environ Res 187:109652

Bode L, Vraga EK (2018) Correction of global health misinformation on social media. Health Commun 33(9):1131-1140

Boelig RC, Manuck T, Oliver EA, Di Mascio D, Saccone G, Bellussi F, Berghella V (2020) Labor and delivery guidance for COVID-19. Am J Obstet Gynecol 2(2):100110

Ceccarelli M, Berretta M, Rullo EV, Nunnari G, Cacopardo B (2020) Editorial-differences and similarities between Severe Acute Respiratory Syndrome (SARS)-CoronaVirus (CoV) and SARSCoV-2. Would a rose by another name smell as sweet? Eur Rev Med Pharmacol Sci 24:2781-2783. https://doi.org/10.26355/ eurrev

Cohen J (2020) Vaccine designers take first shots at COVID-19. Science 368(6486): 14-16

Doğan B, Jebli MB, Shahzad K, Farooq TH, Shahzad U (2020) Investigating the effects of meteorological parameters on COVID-19: case study of New Jersey, United States. Environ Res 191:110148

Dong Y, Mo X, Hu Y, Qi X, Jiang F, Jiang Z, Tong S (2020) Epidemiological characteristics of 2143 pediatric patients with 2019 coronavirus disease in China. Pediatrics. https://doi.org/10.1542/ peds.2020-0702

Ferrante G, Baldissera S, Moghadam PF, Carrozzi G, Trinito MO, Salmaso S (2011) Surveillance of perceptions, knowledge, attitudes and behaviors of the Italian adult population (18-69 years) during the 2009-2010 A/H1N1 influenza pandemic. Eur J Epidemiol 26(3):211-219

Goodchild MF, Glennon JA (2010) Crowdsourcing geographic information for disaster response: a research frontier. Int J Dig Earth 3(3):231-241 
Grodzinsky E, Levander MS (2020) Clinical implications. Underst Fever Body Temp 129-159

Guan WJ, Ni ZY, Hu Y, Liang WH, Ou CQ, He JX, Liu L, Shan H, Lei CL, Hui DS, Du B (2020) Clinical characteristics of coronavirus disease 2019 in China. N Engl J Med 382(18):1708-1720

Hashmi S (2020) Potential antimicrobial activity of essential oils of some spices on some human pathogens. Indian J Appl Res 9(12)

Hassan P, Azfar A (2003) Securing environmental rights through public interest litigation in South Asia. Va Envtl LJ 22:215

Holshue ML, DeBolt C, Lindquist S, Lofy KH, Wiesman J, Bruce H, Spitters C, Ericson K, Wilkerson S, Tural A, Diaz G (2020) First case of 2019 novel coronavirus in the United States. N Engl J Med 382:929-936. https://doi.org/10.1056/NEJMoa2001191

Hopman J, Allegranzi B, Mehtar S (2020) Managing COVID-19 in low-and middle-income countries. JAMA 323(16):1549-1550

Jamil T, Alam I, Gojobori T, Duarte CM (2020) No evidence for temperature-dependence of the covid-19 epidemic. Front Public Health 26(8):436

Kalra DK, Sikand G, Vijayaraghavan K, Guyton JR (2020) South Asian atherosclerotic risk. J Clin Lipidol 14(2):161-169

Kariwa H, Fujii N, Takashima I (2006) Inactivation of SARS coronavirus by means of povidone-iodine, physical conditions and chemical reagents. Dermatology 52(3):119-123. https://doi.org/ $10.1159 / 000089211$

Khilji SE (2012) Editor's perspective: does South Asia matter? Rethinking South Asia as relevant in international business research. South Asian J Bus Manag Cases 1(1):8-21

Larsen SB, Cowley CJ, Fuchs E (2020) Epithelial cells: liaisons of immunity. Curr Opin Immunol 62:45-53

Lee WS, Wheatley AK, Kent SJ, DeKosky BJ (2020) Antibodydependent enhancement and SARS-CoV-2 vaccines and therapies. Nat Microbiol 5(10):1185-1191

Leiner BM, Cerf VG, Clark DD, Kahn RE, Kleinrock L, Lynch DC, Postel J, Roberts LG, Wolff S (2009) A brief history of the Internet. Comput Commun Rev 39(5):22-31

Leslie P, McCabe JT, Bollig M, Greiner C, Fratkin E, Galaty JG, Homewood K, Lansing S, Lu F, Moran EF, Nelson F (2013) Response diversity and resilience in social-ecological systems. Curr Anthropol 54(2):114-143. https://doi.org/10.1086/669563

Li Q, Guan X, Wu P, Wang X, Zhou L, Tong Y, Ren R, Leung KS, Lau EH, Li Q, Guan X, Wu P, Wang X, Zhou L, Tong Y, Ren R, Leung KS, Lau EH, Wong JY, Xing X (2020) Early transmission dynamics in Wuhan, China, of novel coronavirus-infected pneumonia. N Engl J Med 382:1199-1207

Liu WJ, Yuan C, Yu ML, Li P, Yan JB (2020) Detection of novel coronavirus by rt-pcr in stool specimen from asymptomatic child, China. Emerg Infect Dis. https://doi.org/10.3201/eid2606.200301

Livingston E, Bucher K, Rekito A (2020) Coronavirus disease 2019 and influenza 2019-2020. JAMA 323(12):1122-1122

Ma Y, Zhao Y, Liu J, He X, Wang B, Fu S, Yan J, Niu J, Zhou J, Luo B (2020) Effects of temperature variation and humidity on the death of COVID-19 in Wuhan, China. Sci Total Environ 26:138226

Ministry of Health of the Republic of Panama (2020) MINSA. http:// www.minsa.gob.pa

Mittal R, Ni R, Seo JH (2020) The flow physics of COVID-19. J Fluid Mech 894:1-14. https://doi.org/10.1017/jfm.2020.330

Nabity-Grover T, Cheung CM, Thatcher JB (2020) Inside out and outside in: How the COVID-19 pandemic affects self-disclosure on social media. Int J Inf Manage 1(55):102188. https://doi.org/10. 1016/j.ijinfomgt.2020.102188

Qureshi N, Shaikh BT (2006) Myths, fallacies and misconceptions: applying social marketing for promoting appropriate health seeking behavior in Pakistan. Anthropol Med 13(2):131-139
Rehman A, Ashraf F, Javed Z, Hussain M, Farooq TH, Shakoor A, Shahzad SM (2020) The nexus between meteorological parameters and COVID-19 pandemic: case of Islamabad, Pakistan. Environ Sustain 17:1-5

Reyna VF (2012) Risk perception and communication in vaccination decisions: a fuzzy-trace theory approach. Vaccine 30(25):3790-3797

Sakamoto F, Yamada H, Suzuki C, Sugiura H, Tokuda Y (2010) Increased use of alcohol-based hand sanitizers and successful eradication of methicillin-resistant Staphylococcus aureus from a neonatal intensive care unit: a multivariate time series analysis. Am J Infect Control 38(7):529-534

Şanlier N, Gencer F (2020) Role of spices in the treatment of diabetes mellitus: a mini review. Trends Food Sci Technol 99:441-449. https://doi.org/10.1016/j.tifs.2020.03.018

Shakoor A, Chen X, Farooq TH, Shahzad U, Ashraf F, Rehman A, Sahar NE, Yan W (2020) Fluctuations in environmental pollutants and air quality during the lockdown in the USA and China: two sides of COVID-19 pandemic. Air Qual Atmos Health 13(11):1335-1342

She J, Jiang J, Ye L, Hu L, Bai C, Song Y (2019) Novel coronavirus of pneumonia in Wuhan, China: emerging attack and management strategies. J Transl Med 9(1):1-7. https://doi.org/10.1186/ s40169-020-00271-Z

Shi P, Dong Y, Yan H, Zhao C, Li X, Liu W, He M, Tang S, Xi S (2020) Impact of temperature on the dynamics of the COVID-19 outbreak in China. Sci Total Environ 23:138890. https://doi.org/10.1016/j. scitotenv.2020.138890

Vashishtha VM, Kumar P (2020) Development of SARS-CoV-2 vaccines: challenges, risks, and the way forward. Hum Vaccines Immunother 5:1-5

Wacker M (2020) Common nutrition and health issues. In: Nutritional and Health Aspects of Food in Western Europe, pp 159-171

Wang J, Tang K, Feng K, Lv W (2020) High temperature and high humidity reduce the transmission of COVID-19. SSRN 3551767

Wölfel R, Corman VM, Guggemos W, Seilmaier M, Zange S, Müller MA, Niemeyer D, Jones TC, Vollmar P, Rothe C, Hoelscher M (2020) Virological assessment of hospitalized patients with COVID-2019. Nature 581(7809):465-469. https://doi.org/10. $1038 / \mathrm{s} 41586-020-2196-\mathrm{x}$

World Health Organization (2020) Coronavirus (WHO) https://www. who.int/health-topics/coronavirus

Wu Z, McGoogan JM (2020) Outbreak in China: summary of a report of 72314 cases from the Chinese center for disease control and prevention. JAMA 323:1239-1242. https://doi.org/10.1001/jama. 2020.2648

Yoshida S, Kasuga S, Hayashi NO, Ushiroguchi T, Matsuura H, Nakagawa S (1987) Antifungal activity of ajoene derived from garlic. Appl Environ Microbiol 53(3):615-617

Zhang NN, Li XF, Deng YQ, Zhao H, Huang YJ, Yang G, Huang WJ, Gao P, Zhou C, Zhang RR, Guo Y (2020) A thermostable mRNA vaccine against COVID-19. Cell 182(5):1271-1283

Zhu Y, Xie J (2020) Association between ambient temperature and COVID-19 infection in 122 cities from China. Sci Total Environ 724:138201. https://doi.org/10.1016/j.scitotenv.2020.138201

Publisher's note Springer Nature remains neutral with regard to jurisdictional claims in published maps and institutional affiliations. 